\title{
The potential role of aid in escaping the middle- income trap
}

\author{
TIMOTHY YAW ACHEAMPONG ${ }^{1 *}$ (1) and BEÁTA UDVARI ${ }^{2}$
}

\author{
${ }^{1}$ Doctoral School in Economics, University of Szeged, Szeged, Hungary \\ ${ }^{2}$ Faculty of Economics and Business Administration, University of Szeged, Szeged, Hungary
}

Received: April 14, 2020 • Revised manuscript received: June 30, $2020 \bullet$ Accepted: August 04, 2020

Published online: October 10, 2020

(C) 2020 The Author(s)

\begin{abstract}
Recently, the middle-income trap (MIT) has gained considerable attention - besides European countries, several African, Asian, and Latin-American developing countries are also affected. Many countries have remained in the middle-income bracket for decades, whilst only a few have advanced to high-income status. Felipe et al. in 2012 showed that an annual growth rate of at least 3.5 and $4.7 \%$ sustained for a period of 14 and 28 years is required respectively for upper-middle-income and lower-middle-income countries to escape the MIT. Economic growth is influenced by several factors including foreign aid received. Thus, in this study, we aim to answer the question of how aid affects economic growth in middle-income countries and whether aid may contribute to escaping the MIT. Focusing on the countries that have remained in the middle-income group between 1990 and 2017, our analysis confirms that aid contributes to economic growth; however, the impact is positive in the upper-middle-income countries and negative in the lowermiddle-income countries. Aid is therefore, likely to be more effective in helping the upper-middle income countries to escape the MIT but not the lower-middle income countries.
\end{abstract}

\section{KEYWORDS}

middle-income trap, foreign aid, economic growth, external development finance

\section{JEL-CODES}

F35, F43, 019, 057

\footnotetext{
*Corresponding author. E-mail: yamebah@yahoo.com
} 


\section{INTRODUCTION}

The World Bank annually classifies countries into income groups based on their gross national income (GNI) per capita. Based on this classification system, there are low-income, middleincome, and high-income countries (World Bank 2020). The middle-income countries - in which 75\% of the current global population lives (Prydz - Wadhwa 2019) - are further divided into two income groups, namely lower-middle-income and upper-middle-income countries. According to the UNDP (2019), it is desirable for all countries to move from lower to higher income brackets because higher income levels are positively correlated with higher levels of human development and well-being, both within and across nations. That notwithstanding, available evidence suggests that when countries enter the middle-income bracket, they are in danger of not advancing to high-income status because of peculiar economic developmental challenges which, if not addressed, can result in perpetual economic growth slowdowns and stagnation (Aiyar et al. 2013; Eichengreen et al. 2013; Glawe - Wagner 2016).

Out of 101 middle-income countries in 1960, only 13 went on to become high-income countries by 2008 (World Bank 2012; Glawe - Wagner 2016). This relatively low number suggests that there is a kind of trap that affects middle-income countries. The so-called middleincome trap (hereafter MIT) has become a global development issue due to its associated negative welfare consequences such as income inequality, political instability, low human capital, and high unemployment in the affected countries (Glawe - Wagner 2016; World Bank 2012). Meanwhile, ending all forms of inequalities both within and across nations is a global development priority highlighted in the most recent Human Development Report 2019 (UNDP 2019) and the Sustainable Development Goals (SDGs) adopted by world leaders in 2015 (UN 2015, 2017). These have prompted international development organizations such as the United Nations, IMF, World Bank, and the World Economic Forum to increase awareness about the need for countries to avoid and escape the MIT.

In academia, scholars such as Aiyar et al. (2013), Eichengreen et al. (2013), Gill and Kharas (2015), Glawe and Wagner (2016, 2018), Han and Wei (2016), Wang et al. (2018); as well as Soyyigit (2019) have investigated the MIT and how countries can escape it. Currently, there is still a debate in the literature as to the exact cause or solution to the MIT. Some of the factors attributed to the MIT include unfavorable demographics, bad governance, weak institutions, poor infrastructure, low human capital, as well as low technological development and unfavorable trade structure (Aiyar et al. 2013; Glawe - Wagner 2016; Soyyiğit 2019; World Bank 2012). Despite the diverse perspectives, many researchers agree that a certain level of economic growth is needed to escape the MIT. However, economic growth is determined by several domestic and foreign factors; one of which is foreign aid. Meanwhile, over the past 20-30 years, foreign aid has been used to achieve the various, diverse, and changing objectives of both donors and governments, including poverty reduction, capacity building, export promotion, employment, foreign currency generation, growth, etc (Edwards 2015; Pieterse 2010). Furthermore, the literature on aid effectiveness identifies various channels through which aid affects economic growth and development (Edwards 2015).

Although the nexus between foreign aid and economic growth has been previously analyzed by several researchers, the role of foreign aid in escaping the MIT has received little attention. Considering that previous studies have also produced mixed results regarding the impact of aid on growth, it is still necessary to understand the relationship between foreign aid and growth in 
middle-income countries within the framework of the MIT. In this paper, we aim to contribute to the literature by focusing on this special country group (middle-income countries) and by analyzing the direct impact of aid on growth in these countries. Our analyses also contributes to the MIT-literature by introducing another factor with the potential to support countries in escaping the MIT. This study is based on the premise that economic growth is the basic requirement to overcome the MIT. Therefore, since foreign aid may have a positive impact on economic growth and development, it may also be crucial for overcoming the MIT.

The structure of the remaining sections of the paper is as follows: First, we introduce the concept of MIT; then we summarize the relevant literature on this topic, with a special focus on the role of economic growth in escaping the MIT, and the nexus between aid and middle-income countries. In the subsequent section, we detail the methodology with which we analyze the role of aid in overcoming the MIT. The paper ends with the results, conclusions, and policy recommendations.

\section{THE MIDDLE-INCOME TRAP AND FOREIGN AID}

\subsection{The concept of middle-income countries and the middle-income trap}

There is currently no single definition in the literature as to what constitutes the MIT or how to determine if a country is in the MIT or not. According to Gill and Kharas (2015) who introduced the term 'middle income trap' in a 2007 World Bank Report titled 'An East Asian Renaissance, Ideas for Economic Growth', the MIT concept emerged due to the inability of the existing economic growth theories to inform development policy satisfactorily in middle-income countries. Until the emergence of the MIT concept, the endogenous growth theories and the Solow growth model had been the foremost economic frameworks put forth to explain the differences in economic performance of nations. However, Gill and Kharas (2015) posit that though the endogenous growth theories and the Solow growth model were successful in addressing growth problems in high-income and low-income countries respectively, neither of these frameworks were satisfactory in understanding and addressing the nature of economic growth challenges in middle-income countries. This gave rise to the idea of the MIT which is a relatively new phenomena, conceptually at least (Glawe - Wagner 2016).

Although various definitions of the MIT have been proposed in literature, the term is generally accepted to describe the phenomena whereby countries that have reached middleincome status with rapid economic growth are unable to catch up to the developed countries and achieve high-income status. Rather, these countries get stuck in the middle-income range (Gill - Kharas 2015). According to Glawe and Wagner (2016) there are two groups of definitions for the MIT (Fig. 1). These are the "primarily theoretical definitions" and the "primarily empirical or quantitative definitions". The empirical/quantitative definitions are further divided into relative and absolute definitions.

Regarding the primarily theoretical definitions, some of the earliest authors on the MIT such as Garrett (2004), Gill and Kharas (2007), Ohno (2009), and Kharas and Kohli (2011) define the MIT as a form of political failure characterized by missing structural and institutional reforms (Glawe - Wagner 2016; World Bank 2012). Several models including the dual-sector model developed by W. Arthur Lewis (1954), Rostow's Stages of Economic Growth (1960), as well as the 'Stages of the catching up process' in Ohno's middle income trap model (Ohno 2009) are 


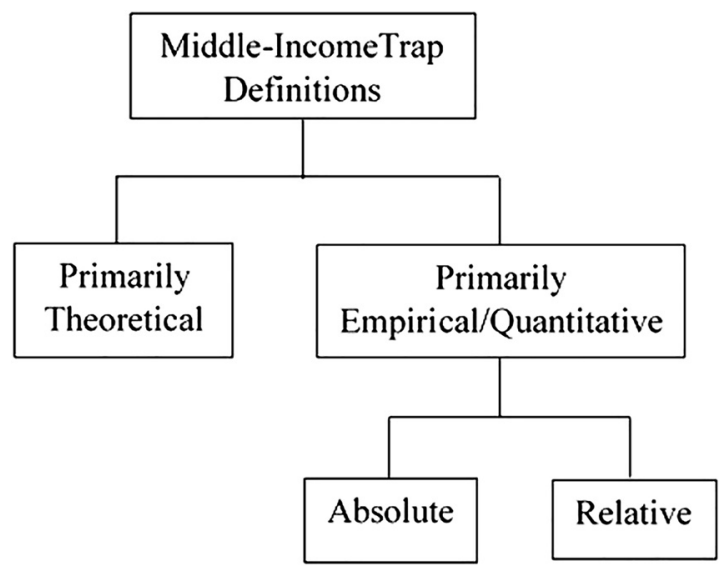

Fig. 1. Classification of middle-income trap definitions.

Source: authors, based on Glawe - Wagner (2016).

among the numerous models that provide the basis for theoretical definitions of the MIT. The core argument of the theoretical definitions of MIT is that factors that generate growth in lowincome countries are no longer available once an economy achieves middle-income. From this perspective, every middle-income country is potentially in danger of becoming stuck in the MIT if they are unable to transform their economies as they climb up the development ladder (Glawe - Wagner 2016). In this regard, a recent study on the relationship between structural transformation and the MIT conducted by Soyyigit (2019) found that the extent to which a country diversifies and produces more sophisticated exports was an important factor for promoting sustainable development in countries that escaped the MIT.

Unlike the theoretical definitions that focus on institutional factors and the structure of economies to classify a country as being in the MIT or not, the empirical definitions of the MIT (absolute and relative) are similar insofar as they both use the per capita income of countries to determine whether they are in the MIT or not. For instance, the absolute definition is based on predetermined national income thresholds. The most widely used indicator from this perspective is the World Bank's classification of countries. This classification system groups countries into four income categories based on the real per capita $\mathrm{GNI}^{1}$ calculated on the basis of the Atlas method ${ }^{2}$ and is annually updated on the $1^{\text {st }}$ of July. Being in the middle-income group itself is not a problem; but rather, what has intrigued development practitioners and researchers

\footnotetext{
${ }^{1}$ For the 2020 fiscal year, lower-middle-income economies are those with a GNI per capita between $\$ 1,026$ and $\$ 3,995$; upper-middle-income economies are those with a GNI per capita between $\$ 3,996$ and $\$ 12,375$; high-income economies are those with a GNI per capita of \$12,376 or more (World Bank 2020).

${ }^{2}$ In terms of methodology, the Atlas conversion factor for any year is calculated by taking the average of a country's exchange rate for that year and its exchange rates for the two preceding years, adjusted for the difference between the rate of inflation in the country and international inflation; the objective of the adjustment is to reduce any changes to the exchange rate caused by inflation (World Bank 2020).
} 
is why so many countries spend long periods in that bracket and find it extremely difficult to advance to the high-income group, coupled with challenges that these countries face.

Some authors such as Glennie (2011) have raised concerns regarding the use of only GNI per capita to represent the development status of countries and recommend other measures like the Human Development Index or the multidimensional poverty index developed by the United Nations Development Programme (UNDP). That notwithstanding, there is empirical evidence which shows a clear relationship between higher income per capita and higher human development indicators. For instance, indicators such as life expectancy, institutional quality, technological advancement, and percentage of the population living in poverty all tend to improve as income per capita increases (Glennie 2011; UNDP 2019). Again, there are various approaches to grouping economies and organizing analysis of development data; however, Prydz and Wadhwa (2019) have observed that the absolute nature of the income thresholds and the long history of the World Bank's classification scheme makes it useful for tracking progress over time. Furthermore, the income classifications influence aid decisions of donors as well as the domestic policy of countries in terms of the nature of external finances they can access to supplement their national budgets and development (Bird - Glennie 2011; Prydz - Wadhwa 2019;OECD 2020). This makes the World Bank's income group classifications based on GNI per capita suitable for investigating the MIT since the income classifications are intended to aggregate and analyze data for groups of similar economies (Prydz - Wadhwa 2019).

Unlike the absolute definition which defines the MIT countries as those stuck within the specific middle-income thresholds, the relative definitions define the MIT by comparing the per capita income of countries to the United States or another developed country. For instance, Woo et al. (2012) define the middle-income range as per capita income between $20 \%$ and $55 \%$ of the USA. Alternatively, Robertson and Ye (2015)argue that a country is in the middle-income range when its per capita income is $8-38 \%$ relative to the US's. Based on the few examples above, Glawe and Wagner (2016) point out that these significant differences in the thresholds lead to great variations in the empirical results in terms of which countries have been caught up in the MIT. In fact, the determination of the 13 countries widely cited as having escaped the MIT between 1960 and 2008 were estimated by the World Bank (2012) using the relative approach.

\subsection{Economic growth and the MIT}

Although the MIT has been conceptualized differently by various authors, there is a general consensus that the MIT is associated with slowdowns in economic growth which prevent middle-income countries from advancing to high-income status, and also when countries spend a long period of time within the middle-income bracket. Some authors consider a country as being stuck in the MIT if they remain in the middle-income range for over 40 years (Glawe Wagner 2016). Felipe et al. (2012) estimate a period longer than 42 years within the middle income bracket in which, a country stuck in the MIT would spend at least 14 years in the lowermiddle-income range and 28 years are spent in the upper-middle-income range. However, Woo et al. (2012) defines the MIT as a period longer than this. According to them, countries that remain in the middle income bracket for more than 50 years can be considered as MITcountries (Woo et al. 2012).

Aside from describing the MIT based on the number of years a country spends within the middle-income bracket, authors such as Aiyar et al. (2013), Eichengreen et al. (2013), 
Felipe et al. (2012) also describe the MIT as economic slowdowns or declines in the growth rate of GDP per capita. For instance, Eichengreen et al. (2013) have observed that countries can be considered as being in the MIT if they experience an average GDP growth of at least 3.5\% for several years, and then step down by at least $2 \%$ between successive seven-year periods. In this regard, Felipe et al. (2012) posit that avoiding the MIT is, therefore, a question of how countries can grow fast enough in order to cross the lower-middle-income segment in at most 28 years, and the upper-middle-income segment in at most 14 years. Based on this hypothesis, to be able to escape the MIT, the countries in the lower-middle-income range would have to grow at least $4.7 \%$ annually, while those in the upper-middle income would have to grow by at least $3.5 \%$ year on year. These studies suggest a steady and sustainable economic growth as essential for escaping the MIT.

\subsection{Potential role of foreign aid in overcoming the MIT}

Economic growth is determined by the interaction of different domestic factors (such as human capital, poverty, inequality, good governance, institutions, technological level, etc.) and international factors (e.g. international trade, FDI, foreign aid, etc.). In the following, we focus on some of the international growth factors with a special emphasis on foreign aid. Developing economies can access a wide range of external sources of finance such as foreign direct investment (FDI), portfolio equity, long-term and short-term loans (private and public), remittances, and other official flows to support their economic growth (UNCTAD 2018). Although FDI has been the largest source of external finance for developing economies over the past decade, UNCTAD (2018) points out that official development assistance (ODA), commonly called foreign aid, is currently the most significant source of external finance for the least developed countries, at 36 per cent of external finance over the period 2013-2017, compared with 21 per cent for FDI over the same period.

The difference between ODA and the other external sources of finance is that ODA is mainly used for development purposes as opposed to FDI; it can also be spent on investments in projects related to the SDGs that might otherwise not be attractive to private sector investors (UNCTAD 2018). Furthermore, ODA does not generally create a liability for the recipient country. ${ }^{3}$ Although existing studies are yet to investigate the role of foreign aid in escaping the MIT, there is ample literature on the role of foreign aid in economic growth and development. According to Todaro and Smith (2015), the role of foreign aid in economic development was featured in the economic growth theories of the 1950s and 1960s, when theorists viewed the process of development as a series of successive stages of economic growth through which all countries must pass. From this perspective, the theorists posited that the right quantity and mixture of savings, investment, and foreign aid were all that was necessary for developing nations to proceed along an economic growth path that had historically been followed by the more developed countries. This linear approach development was however replaced in the 1970s (Todaro - Smith 2015).

Recently, the impacts of aid on economic growth and development have been found to depend on some conditions including good governance and fiscal policy in recipient countries (Collier - Dollar 2001; McGillivray et al. 2005; Doucouliagos - Paldam 2009). Empirical studies on the impact of foreign aid on economic growth and development have also produced mixed

${ }^{3}$ UNCTAD (2018: 12-13) provides details on the recent trend of different external sources of development finance. 
results (Edwards 2015; Udvari - Ampah 2018). Some authors (Askarov - Doucouliagos 2015; Feeny - Vuong 2017) proved the positive relations between aid and economic growth, while Burke and Ahmadi-Esfahani (2006) as well as Rajan and Subramanian (2008) among others could not prove it. The mixed results are well described by Lof et al. (2015), who used the same dataset but a different method as Nowak-Lehman et al. (2012), and received conflicting results. Thus, foreign aid has been numerously criticized for not being effective in achieving its developmental objectives, and there is a perception among some people that "Western donors provided foreign aid either for realizing alternative political goals or for their conscience's sake" (Paragi 2013: 406).

Despite the mixed results in the literature concerning aid effectiveness, some authors argue that external sources of financing including foreign aid are indispensable for economic development due to the capital and financial constraints of developing countries (Jhingan 2011; Todaro - Smith 2015; UNCTAD 2018). Sector-specific analyses have recently gained momentum (Gopalan - Rajan 2016) and have produced more stable results showing the positive impacts of aid on the growth and development of targeted sectors. Birchler and Michaelowa (2016), Riddel and Nino-Zarazúa (2016), Ndikumana and Pickburn (2017), Udvari and Ampah (2018), and Arndt et al. (2015) for instance have observed that foreign aid can facilitate the achievement of socioeconomic development goals if channeled into the appropriate sectors of the economy (e.g. education, health, water, or research and development). Thus, foreign aid continues to be one of the most important sources of international development funds and expertise for most developing countries (Alonzo - Glennie 2015). The SDGs adopted by world leaders in 2015 further emphasize the importance of ODA for developing countries (UN 2015, 2017).

\subsection{Aid in middle-income countries}

The World Bank's income group classifications influence the foreign aid allocation of donors as well as domestic policies of countries, even though governments may not necessarily align their domestic or foreign policy decisions following this categorization. Thus, Prydz and Wadhwa (2019) point out that until recently, the World Bank only used the income classifications for analytical purposes, but they now also affect some operational policies. The OECD's Development Assistance Committee (DAC) also defines developing countries eligible for aid based on the World Bank classification. The OECD (2020a) points out that countries are removed from the DAC list of aid recipients when they exceeded the high-income threshold for three consecutive years. Currently, middle-income countries receive the most ODA. On average, the lower-middle-income countries received the highest ODA over the past decades (Fig. 2).

Several explanations can account for the trend in Fig. 2. For instance, when countries move up the income ladder, it affects their domestic policy decisions because the grants and concessional loans accessible to support their national budgets diminish; thus, OECD (2020b: 9) points out that, "it should be noted that the mix of external finance sources varies for developing countries of different income groups, with least developed countries (LDCs) more dependent on ODA than lower- or middle-income countries".

Donors also make a distinction between recipient countries according to their income level. For instance, the US and the EU Institutions prefer middle-income countries to low-income countries (Baulch 2006). It has also been found that the middle-income countries are more 


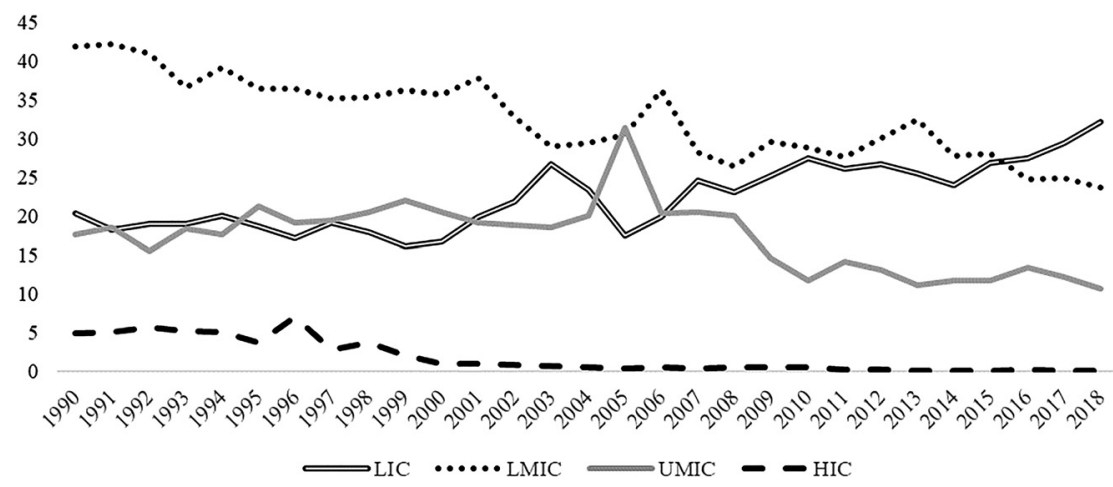

Fig. 2. Share of total ODA in different country groups, 1990-2018 (\%).

Source: authors, based on OECD DAC (2020).

attractive to donors in the short term, because, in general, they are more ready to absorb external finance (Bird - Glennie 2011). A case in point is with regard to recent aid allocations for climate finance, which Bird and Glennie (2011) indicate has been weaker to least developed and other low-income countries, whereas the relatively richer (middle-income) countries have been more significant recipients of this aid.

Glennie (2011) reviewed aid from the European Union (EU) to middle-income countries and concluded that international support to middle-income countries, including financial aid, continues to play an important role in global development. He notes that providing aid to middle-income countries may have significant national, regional, and global spillover effects. The author further explains that foreign aid plays two critical roles in middle-income countries: first, as a non-essential catalyst for change and second, in some cases, as part of an orderly graduation process from aid dependence (Glennie 2011). These can explain why the SDGs also encourage donors to fulfill their ODA commitments to developing countries (UN 2015, 2017) and also confirms that aid is an essential development finance source for middle-income countries that can utilize it effectively.

In spite of aid being an important source of development finance to middle-income countries, to the best of our knowledge, the effectiveness of foreign aid is yet to be analyzed within the context of the MIT. Furthermore, the controversies surrounding the foreign aid and economic growth nexus warrant further analyses to understand how this relationship manifests in middleincome countries within the framework of the MIT. We posit that since economic growth is necessary for escaping the MIT and foreign aid may have a positive impact on economic growth and development, then foreign aid may also be crucial for overcoming the MIT. Although the literature on aid effectiveness identifies various channels through which aid affects economic growth and development (Edwards 2015), our analyses focus on the direct impact of aid on growth in middle-income countries, since the overall growth of a country gives an indication of its potential to escape the MIT or not. Thus, this study seeks to investigate the relationship between foreign aid and economic growth in middle-income countries and whether the aid received can help these countries to overcome the MIT. 


\section{METHODOLOGY FOR ANALYZING AID AND ESCAPING THE MIT NEXUS}

\subsection{Countries, data and methods}

The target population for our analyses was all middle-income countries, since the objective of the study was to investigate the potential role of foreign aid in helping middle-income countries attain high-income status. We followed the World Bank's country classification system, and we also consulted its historical data. Our aim was to involve as many countries as possible for as long a period as possible. However, the availability of data influenced the sample countries and time period of the study. The study focused on countries classified as middle-income between the years 1990-2018. The country classifications were based on the previous year's data. In the year 1990, there was a total of 85 countries classified by the World Bank as middle income (Table 1).

By the year 2018, the total number of countries in middle-income range had reduced from 85 in 1990 to 59 . Out of the 85 countries, 23 have since become high-income countries and 3 countries (Democratic Republic of Korea, Syria, and Yemen) have been re-classified as lowincome countries. Out of the 23 countries that were able to escape the MIT, 3 of them (Chile, Poland, and Panama) were able to move from the lower-middle-income bracket to high-income. The other 20 countries moved from the upper-middle-income bracket to high-income within the period 1990-2018 (Fig. 3). A total of 19 countries also moved from the lower-middle-income group to upper-middle-income (LMI to UMI) group.

Nineteen out of the 59 countries that remained in the middle-income bracket from 1990 to 2018 were in the lower-middle-income group whereas 40 were in the upper-middle-income brackets (Fig. 3). However, in this study, the sample countries were limited to countries that had both GNI per capita and ODA data available within the period. Based on these criteria, 30 out of the 59 middle-income countries (51\%) were finally selected for this study (Appendix 1).

Concerning the indicators, we focused on two basic indicators: aid and GNI per capita. In this study, the OECD's definition of aid was utilized. The OECD defines aid or ODA as grants and loans provided by the official sector with the main objective of enhancing economic development and welfare in developing countries, and it has at least a 10 percent concessional element depending on the income level of the recipient country (OECD 2020c). We collected aid

Table 1. Distribution of middle-income countries in 1990

\begin{tabular}{|l|c|c|c|}
\hline Geographical region & Lower-middle & Upper-middle & Total \\
\hline East Asia \& Pacific & 11 & 5 & 16 \\
\hline Europe \& Central Asia & 5 & 5 & 10 \\
\hline Latin America \& Caribbean & 20 & 10 & 30 \\
\hline Middle East \& North Africa & 9 & 6 & 15 \\
\hline Sub-Saharan Africa & 11 & 3 & 14 \\
\hline Total & 56 & 29 & 85 \\
\hline
\end{tabular}

Source: authors, based on World Bank (2019a). 


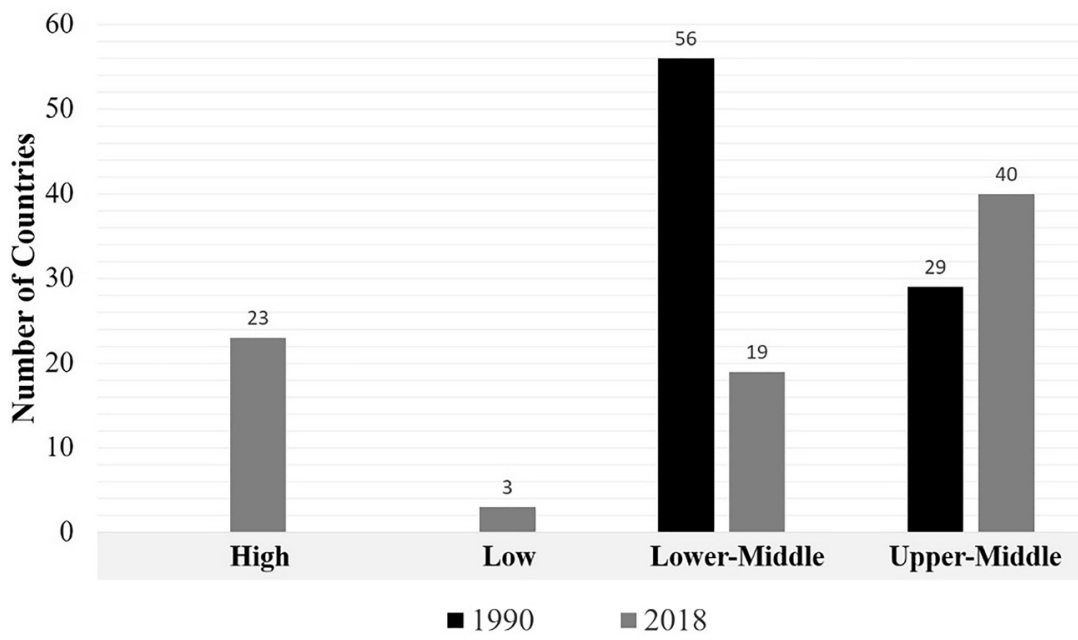

Fig. 3. Number of 1990 middle-income countries in 2018 by income group. Source: authors, based on World Bank (2019a).

data from the OECD QWIDS database (OECD 2019). In the case of South Africa which had missing aid data from 1990 to 1992 , ' 0 ' was used to indicate that the country received no aid in those years. In the analysis we also used ODA per capita to eliminate the distorting effect of the size of the country. For calculating the per capita indicator, we used population data from the UNCTADStat database (UNCTAD 2020).

GNI per capita represented economic growth. Economic growth is usually measured by GDP per capita. Since the focus of this study was to investigate the role of aid in escaping the MIT, GNI per capita was the variable of choice because this indicator is used to classify countries into different income groups. Two sources of GNI per capita were used for comparison purposes. On the one hand, we collected the general GNI per capita data from the UNCTADStat database. On the other hand, we also collected GNI per capita calculated with the Atlas method from the World Bank's database, since it is used to classify countries into income groups. In the case of Iran which had GNI per capita data missing from 1991 to 1994, the missing data was estimated using equation (1):

$$
x_{i+1}=x_{i}+\left(\frac{x_{i+1+n}-x_{i}}{n+1}\right)
$$

where $i=1,2,3, \ldots, \mathrm{n} ; x_{i+1}$ is the missing data; $x_{i}$ is the data for the previous year of missing data; $n$ is the number of years of missing data; and $x_{i+1+n}$ is data for the year after the last year of missing data.

All the data was collected for the years 1990-2017, since 2017 is the last year for which data was available. This represents a period of 28 years which Felipe et al. (2012) posit as the maximum number of years countries need to avoid spending in any of the middle-income brackets if they are to escape the MIT. In the regression models, we also included FDI measured as inward flows in US dollars at current prices in millions, from UNCTADStat. Since FDI is 
currently the largest source of external development finance to developing economies, this was done to be able to compare the relative impact of aid and FDI on the growth of the sample countries holding other explanatory variables of GNI per capita constant.

For the analysis, we used descriptive statistics, correlation analysis, and regression analysis. The descriptive statistics were used to describe the distribution and trend in foreign aid and economic growth in the sample countries. Pearson's Moment Correlation analysis was also conducted to investigate if there was a significant relationship between the ODA flows and GNI per capita growth in the sample countries. Finally, regression analysis was used to investigate the impact of foreign aid on economic growth in the sample countries over the study period.

\subsection{Regression model}

Since the economic growth of countries is influenced by several factors including savings, investments, human capital, and international trade, various empirical studies on the impact of aid on growth have included different variations of these variables. Edwards (2015) also points out that some works have analyzed whether aid only works under certain conditions, or whether a minimal degree of institutional development is required for aid to yield desired outcomes. These studies have considered nonlinear functional forms, and have investigated if there are meaningful interactions between aid and other variables, such as the degree of literacy, the level of corruption, the extent of macroeconomic stability, institutional strength, the quality of overall economic policies, and geography. Most of these studies also relied on cross-country or panel data and made use of GDP as the dependent variable. The selection of variables for this study took these empirical studies into consideration; however, our final model is based on the objectives of this study and the availability of data. We used GNI per capita as a dependent variable and aid and FDI as the main independent variables. Following the approach used byNowakLehmann et al. (2012), we concentrated on the long-run relationship between aid and the level of per capita income rather than the growth rate of per capita income in order to avoid spurious regression problems.

A unique addition to our model is the insertion of interaction terms between foreign aid and the income group of the countries (LMI* ODA and $\mathrm{UMI}^{\star} \mathrm{ODA}$ ), which allows distinguishing between the impact of aid in the LMI and UMI countries respectively. This was done in order to determine if the effect of aid on growth and the potential of aid in escaping the MIT was the same for countries in different income groups or not. We also aimed to introduce good governance indicators into our model to be able to capture some of the conditions of aid effectiveness (discussed earlier) in the respective income groups; however, due to unavailability of data to cover the entire study period, we ran correlation analysis between two worldwide governance indicators and our target variable (Appendix 2) to help explain some of the findings of our regression model.

Because of the wide dispersion between the variables among countries, there was a need to rescale the variables. Thus, GNI per capita was standardized by converting each value into logs to obtain LnGNI per capita. Because some of the countries recorded negative values for ODA and FDI respectively, these variables could not be logged but rather were rescaled by converting the ODA and FDI into z-scores to obtain ZODA and ZFDI respectively. Thus, our general model can be depicted as: 


$$
\mathrm{LnGNIPC}=\mathrm{C}_{0}+\beta \mathrm{ZODA}+\beta \mathrm{ZFDI}+\beta(\mathrm{LMI} * \mathrm{ODA})+\beta(\mathrm{UMI} * \mathrm{ODA})+e
$$

Preliminary analyses were conducted to ensure that there was no multicollinearity among the independent variables. The dataset was analyzed using various regression models including the fixed effects and random effects models, but these did not meet the normality test. The dynamic panel model was eventually selected because it deals with some of the dangers in analyzing per capita income and aid relationships as identified byNowak-Lehmann et al. (2012), such as correcting for autocorrelation. The dynamic panel model also deals with the problems of endogeneity and heteroscedasticity (Contrell - Lucchetti 2019). Since dynamic panel models are suitable when dependent and independent variables are related contemporaneously, and also across historical (lagged) values, the use of a two-step dynamic model was appropriate for this study. The stationarity and Sargan over-identification tests were also conducted to ensure that both the assumptions of unit root and validity of instruments were not violated.

According to Contrell and Lucchetti (2019), the dynamic linear panel regression model can be represented as follows (in notation based on Arellano 2003):

$$
y_{i t}=\alpha y_{i, t-i}+\beta^{\prime} x_{i t}+\eta_{i}+v_{i t}
$$

Where $y$ is the dependent variable; $x$ represents the explanatory variables; $\alpha$ is the coefficient of the lag of the dependent variable; $\beta$ is the coefficient for time independent variables; $\eta_{i}$ is the cross-section effect; and $v_{i t}$ is the white noise or error term. When the explanatory variables are also lagged as was desire in our study, Arellano's equation can be represented as:

$$
y_{i t}=\alpha y_{i, t-i}+\beta_{0}+\beta_{1} x_{i t}+\beta_{2} x_{i, t-1}+\eta_{i}+v_{i t}
$$

Based on our model,Eq. (4) can be summarized as follows:

$$
y_{i t}=\alpha y_{i, t-i}+\beta_{0}+\sum_{j=1}^{4} \sum_{i=0}^{3} \beta_{i+1} x_{j, t-i}+\eta_{i}+v_{i t}
$$

where $y$ is the independent variable (LnGNIPC); $\beta_{0}$ is the constant; $t$ is the time period; $x_{1}$ is ZODA; $x_{2}$ is ZFDI; $x_{3}$ is the LMI*ODA; $x_{4}$ is the LMI*FDI; $x_{1, t}$ is the current time period; $x_{1, t-1}$ is the first lag; $x_{1, t-2}$ is the second lag; and $x_{1, t-3}$ is the third lag. Due to the near perfect or exact collinearity between the LMI*ODA and UMI*ODA variables on the one hand and the LMI*FDI and UMI*FDI on the other, we used two models to test our research questions. In the second model, $x_{3}$ in Eq. (5) was replaced by UMI*ODA whereas $x_{4}$ was replaced by UMI*FDI. The results for the various analyses are discussed in the next section.

\section{RESULTS}

\subsection{Descriptive analysis}

A descriptive analysis of the total ODA and GNI per capita growth rates of the sample countries indicates that the Republic of Congo recorded the lowest GNI per capita growth of $-27.33 \%$ in 1995. This was 2 years before the country was plunged into a bloody civil war. The Republic of Congo also recorded the highest GNI per growth rate in a single year (28.44\%) in 2015. In terms of ODA, Thailand recorded the lowest ODA of -938.59 million USD in 2003. This means that in 
Table 2. Descriptive statistics for ODA and GNI per capita growth rates, 1990-2017

\begin{tabular}{|l|c|r|r|r|c|}
\hline & \multicolumn{1}{|c|}{$\mathbf{N}$} & \multicolumn{1}{c|}{ Minimum } & \multicolumn{1}{c|}{ Maximum } & \multicolumn{1}{c|}{ Mean } & Std. Deviation \\
\hline Total ODA (million USD) & 840 & -938.59 & $3,609.09$ & 377.25 & 474.48 \\
\hline ODA per capita - average (USD) & 840 & -0.02 & 0.39 & 0.04 & 0.05 \\
\hline GNI per capita growth rate & 840 & -27.33 & 28.44 & 2.00 & 4.56 \\
\hline
\end{tabular}

Source: authors.

2003, Thailand was a net donor instead of aid recipient. On the other hand, Turkey received the highest volume of ODA in a single year of 3,609.09 million USD in 2016 (Table 2).

Descriptive analysis of the total ODA and average ODA received by income groups revealed that over the study period, the lower-middle-income countries that moved to the upper-middleincome bracket (LMI to UMI) received the most ODA, followed by the LMI countries that remained in the lower-middle-income group (Fig. 4). However, on average, the countries that remained in the lower-middle-income group received the most ODA. Out of the total ODA allocated to the sample countries over the study period, the countries which remained in the upper-middle-income (UMI) bracket received a lower proportion (13\%) of the total ODA (Fig. 4). The findings of this study are consistent with the global trends depicted in Fig. 2.

\subsection{Relationship between ODA and GNI per capita in middle-income countries}

The results of the correlation analysis for ODA and GNI per capita for all the sample countries reveal no significant relationship between the ODA received in those countries and their GNI per capita. When the same analysis was done with ODA per capita however, there was a significant negative relationship (Table 3). Since we assumed that the heterogeneity of the sample countries influenced the results, we split the sample into 3 different groups.

To further understand the relationship between ODA and economic growth among the sample countries, the study also compared correlation results for the middle-income countries

$\square$ Sum of ODA in million USD (Left Axis) — Average of ODA in million USD (Right Axis)

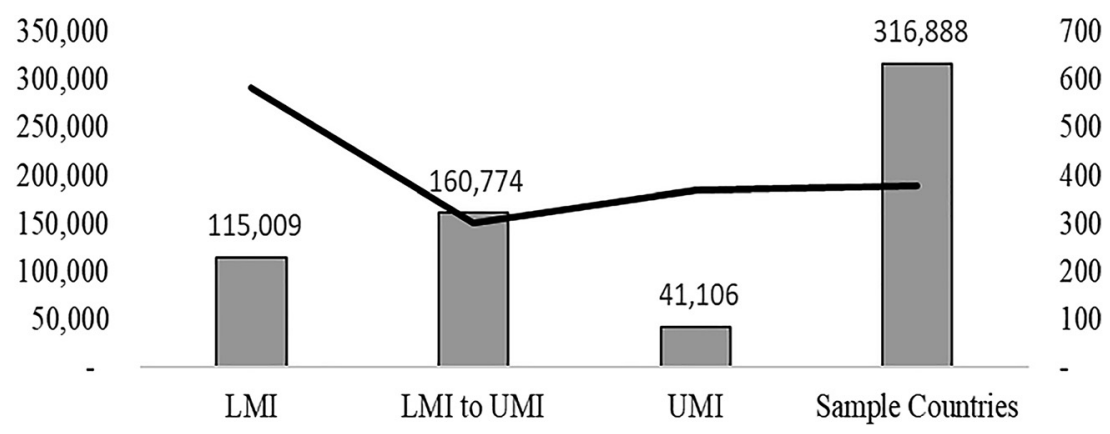

Fig. 4. Distribution of ODA by income group of countries 1990-2017.

Source: authors. 
Table 3. ODA and GNI per capita correlation results for all sample countries

\begin{tabular}{|l|c|c|c|}
\hline \multicolumn{2}{|c|}{} & GNI per capita & GNI per capita Atlas Method \\
\hline \multirow{3}{*}{ ODA } & Pearson Correlation & 0.056 & 0.057 \\
\cline { 2 - 4 } & Sig. (2-tailed) & 0.107 & 0.098 \\
\cline { 2 - 4 } & $\mathrm{N}$ & 840 & 840 \\
\hline \multirow{3}{*}{ ODA/capita } & Pearson Correlation & $-0.127^{* *}$ & $-0.126^{* *}$ \\
\cline { 2 - 4 } & Sig. (2-tailed) & 0.00 & 0.00 \\
\cline { 2 - 4 } & $\mathrm{N}$ & 840 & 840 \\
\hline
\end{tabular}

${ }^{* *}$ Correlation is significant at the 0.01 level (2-tailed).

Source: authors.

that moved from lower-middle-income to upper-middle-income and lower-middle-income countries that remained in the same income bracket over the study period. The study finds that the relationship between the GNI per capita and ODA in the countries that remained in lowermiddle-income group was not significant. However, the relationship in the countries that remained in the upper-middle-income bracket as well as those countries that moved from the lower-middle-income to upper-middle income group was significant and positive, $\mathrm{R}=0.366$ and $\mathrm{R}=0.199$ respectively in the case of the Atlas method (Table 4).

The correlation results in Table 4 show that the relationship between ODA and GNI per capita is stronger in countries with higher income levels. Although the relationship was not strong, the findings still suggest that foreign aid plays a significant role in economic growth and therefore it has a potential to help countries escape the MIT. The findings also suggest that aid

Table 4. Relationship between ODA and GNI by income status 1990-2017

\begin{tabular}{|c|c|c|c|c|c|c|c|}
\hline & \multirow[b]{2}{*}{ Results } & \multicolumn{2}{|c|}{ Remained LMI } & \multicolumn{2}{|c|}{ Remained UMI } & \multicolumn{2}{|c|}{ LMI to UMI } \\
\hline & & GNIPC & Atlas & GNIPC & Atlas & GNIPC & Atlas \\
\hline \multirow[t]{3}{*}{ ODA } & $\begin{array}{l}\text { Pearson } \\
\text { Correlation }\end{array}$ & 0.063 & -0.05 & $0.354 * *$ & $0.366 * *$ & $0.192 * *$ & $0.199 * *$ \\
\hline & Sig. (2-tailed) & 0.383 & 0.513 & 0.00 & 0.00 & 0.00 & 0.00 \\
\hline & $N$ & 196 & 196 & 112 & 112 & 532 & 532 \\
\hline \multirow[t]{3}{*}{$\begin{array}{r}\text { ODA per } \\
\text { capita }\end{array}$} & $\begin{array}{l}\text { Pearson } \\
\text { Correlation }\end{array}$ & -0.047 & 0.012 & -0.04 & -0.06 & -0.045 & -0.045 \\
\hline & Sig. (2-tailed) & 0.515 & 0.872 & 0.648 & 0.507 & 0.305 & 0.303 \\
\hline & $\mathrm{N}$ & 196 & 196 & 112 & 112 & 532 & 532 \\
\hline
\end{tabular}

${ }^{* *}$ Correlation is significant at the 0.01 level (2-tailed).

Source: authors. 
Table 5. Results of two-step dynamic panel regression models (720 observations, 30 cross-sectional units, H-matrix as per 0x/DPD; dependent variable: LnGNIPC)

\begin{tabular}{|c|c|c|c|c|}
\hline \multirow[b]{2}{*}{ Explanatory variables } & \multicolumn{2}{|c|}{ Model 1} & \multicolumn{2}{|c|}{ Model 2} \\
\hline & Coefficient & $P$-value & Coefficient & $P$-value \\
\hline LnGNIPC(-1) & 0.0748651 & 0.4102 & 0.0607598 & 0.5557 \\
\hline const & 0.0115566 & 0.4164 & 0.0113822 & 0.3769 \\
\hline ZODA & 0.0204052 & 0.7022 & -0.108436 & 0.1278 \\
\hline ZODA_1 & 0.108301 & 0.2013 & -0.0506180 & 0.5784 \\
\hline ZODA_2 & 0.144526 & $0.0295^{* *}$ & -0.176195 & $0.0474 * *$ \\
\hline ZODA_3 & 0.101478 & 0.2649 & -0.151273 & 0.1294 \\
\hline ZFDI & 0.152776 & $<0.0001^{* * *}$ & 1.91289 & $<0.0001^{* * *}$ \\
\hline ZFDI_1 & -0.0643031 & 0.1453 & 0.0948979 & 0.7448 \\
\hline ZFDI_2 & -0.0152416 & 0.7791 & 0.617416 & $0.0068 * * *$ \\
\hline ZFDI_3 & -0.0149623 & 0.7640 & 0.307782 & 0.1774 \\
\hline LMIZODA & -0.134173 & $0.0646 *$ & - & - \\
\hline LMIZODA_1 & -0.160883 & 0.1566 & - & - \\
\hline LMIZODA_2 & -0.305886 & $0.0055^{* * *}$ & - & - \\
\hline LMIZODA_3 & -0.241899 & $0.0890 *$ & - & - \\
\hline UMIZODA & - & - & 0.130272 & $0.0947 *$ \\
\hline UMIZODA(-1) & - & - & 0.150645 & 0.1534 \\
\hline UMIZODA(-2) & - & - & 0.316151 & $0.0097^{* * *}$ \\
\hline UMIZODA(-3) & - & - & 0.250401 & 0.1331 \\
\hline LMI*ZFDI & 1.72791 & $<0.0001 * * *$ & - & - \\
\hline LMI*ZFDI(-1) & 0.121724 & 0.6947 & - & - \\
\hline LMIZFDI(-2) & 0.610710 & $0.0080 * * *$ & - & - \\
\hline LMIZFDI(-3) & 0.335879 & 0.2164 & - & - \\
\hline UMIZFDI & - & - & -1.76259 & $<0.0001^{* * *}$ \\
\hline UMIZFDI(-1) & - & - & -0.156420 & 0.5816 \\
\hline UMIZFDI(-2) & - & - & -0.631798 & $0.0171 * *$ \\
\hline UMIZFDI(-3) & - & - & -0.314218 & 0.2258 \\
\hline Sargan (J) Test & 27.5989 & 1.0000 & 27.383 & 1.0000 \\
\hline
\end{tabular}

***Significant at $1 \%$ level; $* *$ Significant at $5 \%$ level; *Significant at $10 \%$ level.

Source: authors. 
may been more effective in promoting economic growth in upper-middle-income countries than in lower-middle-income countries, even though the descriptive analysis indicates that the lowermiddle-income countries receive more aid (Fig. 4). Our regression results shed more light on this apparent trend (Table 5).

As indicated earlier, the objective of the regression analysis was to investigate the impact of aid on growth in the middle-income countries and to determine if the impact was different in the lower- and upper-middle income countries respectively. The study finds that in both regression models, the previous two years' ODA had a significant impact on the current year's GNI per capita for the interactions between income group of countries and aid (i.e. $\mathrm{LMI}^{\star} \mathrm{ODA}$ and $\left.\mathrm{UMI}^{\star} \mathrm{ODA}\right)$. However, the most interesting result is that in the case of the LMI countries, the relationship was negative, whereas in the UMI countries the relationship was positive, although the LMI countries received more aid than UMI countries over the study period (Fig. 4). This finding is consistent with our correlation analyses and the mixed results found in the existing literature on aid effectiveness. This finding further suggests that income levels of countries may be a determinant of aid effectiveness with respect to the impact of aid on growth.

Since previous studies have also identified good governance and efficient institutions as conditions for aid effectiveness, the study also tested the relationship between these factors and the income group of countries. The correlation analysis indicates that the performance in governance indicators such as control of corruption and government effectiveness were positively correlated with GNI per capita over the past 15 years; $\mathrm{R}=0.3$ and $\mathrm{R}=0.5$ respectively (See Appendix 2). Therefore, the disparity in the impact of aid on growth in the various countries could be attributed to different institutional factors pertaining to the respective countries. This finding could also explain the observation of Bird and Glennie (2011) that some donors prefer to finance richer countries that are better able to absorb and utilize aid.

Overall, the results of the regression analyses indicate a significant relationship between the previous two years' ODA and the current year's GNI per capita for both models. This implies that the impacts of aid on GNI per capita are long term. However, the impact of aid on growth was not very strong in the study countries. The low impact of foreign aid on the GNI per capita of the countries analyzed gives credence to various authors who have criticized the effectiveness of aid in achieving developmental targets, Pieterse (2010) among them pointing out that other government interventions may be more viable for promoting development than foreign aid projects. The results also indicate that FDI has short-term impacts on GNI per capita, but the impact reduces over time in the first model, whereas in the second model there is a significant long run positive impact of the FDI on GNI per capita. However, contrary to the results for ODA, FDI has a positive and significant long-term impact in the LMI countries, but a negative long-term impact in the UMI countries. These differentiated findings are consistent with current thinking in development economics, which acknowledges that the unique historical, cultural, institutional, and political environments of countries influence their outcomes.

\section{CONCLUSIONS AND RECOMMENDATIONS}

The main aim of this study was to analyze the potential role of foreign aid in escaping the MIT. Our findings show that foreign aid may have the potential to help middle-income countries escape the MIT. However, the study finds that ODA does not have a significant relationship 
with GNI per capita in all the middle-income countries. The correlation between ODA and GNI per capita (Atlas method) was only significant in the UMI group, but not significant in LMI countries, even though the LMI countries receive more aid. Also, the study finds that ODA had a significant positive relationship with GNI per capita in the countries that moved from the lower to upper-middle-income bracket over the study period. This finding is a novelty, because previous studies had considered middle-income countries as a homogeneous group. However, this study shows that even within the middle-income group, the income levels of the different countries may also be a determinant of aid effectiveness. Based on our analyses, we can conclude that the nexus between foreign aid and growth manifests differently in different countries and in different income groups.

The mixed results and weak impact of aid on growth is a clear indication that other factors apart from foreign aid may be more important in promoting economic growth and escaping the MIT. That notwithstanding, since the impact of foreign aid on economic growth is more significant and positive in the UMI countries than the LMI countries, the potential role of aid in overcoming the MIT is stronger in the UMI countries, which are already closer to escaping the MIT because of their higher GNI per capita. Thus, foreign aid has the potential to help some countries to escape the MIT, but this impact is not immediate. It only begins to take effect in subsequent years. Therefore, the potential of foreign aid to boost economic growth is not necessarily guaranteed by increasing ODA flows to developing countries as advocated by the SDG target 17.2. Rather, what is more critical is the ability of the aid recipient countries to use the aid effectively and productively. If used appropriately, it may have a more long-term impact on economic growth.

A limitation of cross section and panel regression analyses for investigating aid effectiveness is that it is unable to explain the intricacies of foreign assistance and the unique historical experiences and institutional environments pertaining to various countries. We therefore recommend that further studies should take these into consideration. Also, if foreign aid is to truly achieve its intended development objectives and contribute to escaping the MIT, then a clear plan on how aid would be applied, including milestones for measuring progress in recipient countries, should be one of the pre-requisites for aid allocation. Finally, countries should also consider their unique factors that may facilitate or inhibit aid effectiveness, if they are to benefit from aid in the long-term.

\section{REFERENCES}

Aiyar, S. - Duval, R. - Puy, D. - Wu, Y. - Zhang, L. (2013): Growth Slowdowns and the Middle-Income Trap. IMF Working Paper WP/13/71.

Alonzo, J. A. - Glennie, J. (2015): What is Development Cooperation? 2016 Development Cooperation Forum Policy Briefs no 1.

Arellano, M. (2003): Panel Data Econometrics. Oxford: Oxford University Press.

Arndt, C. - Jones, S. - Tarp, F. (2015): Assessing Foreign Aid's Long-run Contribution to Growth and Development. World Development 69(5): 6-18.

Askarov, Z. - Doucouliagos, H. (2015): Development Aid and Growth in Transition Countries. World

Development 66(2): 383-399. 
Baulch, B. (2006): Aid distribution and the MDGs. World Development 34(6): 933-950.

Birchler, K. - Michaelowa, K. (2016): Making Aid Work for Education in Developing Countries: An Analysis of Aid Effectiveness for Primary Education Coverage and Quality. International Journal of Educational Development 48(3): 37-52.

Bird, N. - Glennie, J. (2011): Going Beyond Aid Effectiveness to Guide the Delivery of Climate Finance. London: Overseas Development Institute.

Bissio, R. (2013): The Paris Declaration on Aid Effectiveness, in Realizing the Right to Development: Essays in Commemoration of 25 Years of the United Nations Declaration on the Right to Development. New York: United Nations.

Burke, P. J. - Ahmadi-Esfahani, F. Z. (2006): Aid and Growth: A Study of South East Asia. Journal of Asian Economics 17(2): 350-362.

Collier, P. - Dollar, D. (2001): Can the World Cut Poverty in Half? How Policy Reform and Effective Aid Can Meet International Development Goals. World Development 11: 1787-1802.

Contrell, A. - Lucchetti, R. J. (2019): Gretl User's Guide, Gnu Regression, Econometrics and Time-series Library. Boston: Free Software Foundation, Inc.

Doucouliagos, H. - Paldam, M. (2009): The Aid Effectiveness Literature: the Sad Results of 40 Years of Research. Journal of Economic Surveys 23(3): 433-461.

Edwards, S. (2015): Economic Development and the Effectiveness of Foreign Aid: A Historical Perspective. Kyklos 68(3): 277-316.

Eichengreen, B. - Park, D. - Shin, K. (2013): Growth Slowdowns Redux: New Evidence on the Middle Income Trap. Cambridge: National Bureau of Economic Research.

Feeny, S. - Vuong, V. (2017): Explaining Aid Project and Program Success: Findings from Asian Development Bank Interventions. World Development 90(2): 329-343.

Felipe, J. - Abdon, A. - Kumar, U. (2012): Tracking the Middle-income Trap: What Is It, Who Is in It, and Why? Levy Economics Institute of Bard College Working Paper No. 715.

Garrett, G. (2004): Globalization's Missing Middle. Foreign Affairs 83(6): 84-96.

Gill, I. - Kharas, H. (2007): An East Asian Renaissance, Ideas for Economic Growth. Washington DC: World Bank.

Gill, I. - Kharas, H. (2015): The Middle-Income Trap Turns Ten. World Bank Policy Research Working Paper No. 7403.

Glawe, L. - Wagner, H. (2016): The Middle-income Trap - Definitions, Theories and Countries Concerned: A Literature Survey. Hagen: Munich Personal RePEc Archive.

Glawe, L. - Wagner, H. (2018): The Middle-Income Trap 2.0, the Increasing Role of Human Capital in the Age of Automation and Implications for Developing Asia. CEAMeS Discussion Paper No. 15/2018.

Glennie, J. (2011): The Role of Aid to Middle-income Countries: A Contribution to Evolving EU Development Policy. Overseas Development Institute Working Paper 331.

Gopalan, S. - Rajan, R. S. (2016): Has Foreign Aid Been Effective in the Water Supply and Sanitation Sector? Evidence from Panel Data. World Development 85(9): 84-104.

Han, X., Wei, S.J., 2016. Re-examining the Middle Income Trap Hypothesis (MITH): What to Reject and What to Revive? In: Economic Policy 63rd Panel Meeting. De Nederlandsche Bank, Amsterdam.

Jhingan, M. L. (2011): The Economics of Development and Planning 40th Revised and Enlarged Edition. Mayur Vihar, Phase-I. Delhi: Vrinda Publications (P) Ltd.

Kharas, H. - Kohli, H. (2011): What is the Middle Income Trap, Why do Countries Fall into It, and How Can It be Avoided? Global Journal of Emerging Market Economies 3(3): 281-289. 
Lof, M. - Mekasha, T. J. - Tarp, F. (2015): Aid and Income: Another Time-series Perspective. World Development 69(5): 19-30.

McGillivray, M. - Feeny, S. - Hermes, N. - Lensink, R. (2005): It Works; It Doesn't; It Can, but that Depends... 50 Years Contoversery Over the Macroeconomic Impact of Development Aid. UNUWIDER Research Paper No. 2005/54.

Ndikumana, L. - Pickbourn, L. (2017): The Impact of Foreign Aid Allocation on Access to Social Services in Sub-Saharan Africa: The Case of Water and Sanitation. World Development 90(2): 104-114.

Nowak-Lehmann, F. - Dreher, A. - Herzer, D. - Klasen, S. - Martínez-Zarzoso, I. (2012): Does Foreign Aid Really Raise Per Capita Income? A Time Series Perspective. Canadian Journal of Economics 45(1): 288313.

OECD. (2019): Query Wizard for International Development Statistics. Paris: Organisation for Economic Co-operation and Development. https://stats.oecd.org/qwids/. accessed 11 Auguest 2020.

OECD. (2020a): History of DAC Lists of Aid Recipient Countries. Paris: Organisation for Economic Cooperation and Development. http://www.oecd.org/development/financing-sustainable-development/ development-finance-standards/historyofdaclistsofaidrecipientcountries.htm. accessed 11 Auguest 2020.

OECD. (2020b): Six Decades of ODA: Insights and Outlook in the COVID-19 Crisis. Paris: Organisation for Economic Co-operation and Development.

OECD. (2020c): Official Development Assistance - definition and Coverage. Paris: Organisation for Economic Co-operation and Development. http://www.oecd.org/development/financing-sustainabledevelopment/development-finance-standards/officialdevelopmentassistancedefinitionandcoverage.htm. accessed 11 Auguest 2020.

OECD DAC. (2020): Development Finance Data and DAC List of ODA Recipients. Paris: Organisation for Economic Co-operation and Development.

Ohno, K. (2009): Avoiding the Middle-income Trap: Renovating Industrial Policy Formulation in Vietnam. ASEAN Economic Bulletin 26(1) 25-43.

Paragi, B. (2013): First Impressions and Perceived Roles: Palestinian Perceptions on Foreign Aid. Society and Economy 35(3): 389-410.

Prydz, E. B. - Wadhwa, D. (2019): Classifying Countries by Income. Washington DC: World Bank.

Pieterse, J. N. (2010): Development Theory. London, Thousand Oaks, New Delhi: Sage.

Rajan, R. G. - Subramanian, A. (2008): Aid and Growth: What Does the Cross-country Evidence Really Show? The Review of Economics and Statistics 90(4): 643-665.

Riddell, A. - Niño-Zarazúa, M. (2016): The Effectiveness of Foreign Aid to Education: What Can be Learned? International Journal of Educational Development 48(3): 23-36.

Robertson, P. E. - Ye, L. (2015): On the Existence of a Middle-Income Trap. University of Western Australia Working Paper 13/12.

Soyyigit, S. (2019): The Relationship Between Middle Income Trap and Structural Transformation: The Case of Selected Countries. CEJEME 11(4): 217-235.

Todaro, M. P. - Smith, S. C. (2015): Economic Development, 12th Edition. Upper Sadle River: Pearson. Udvari, B. - Ampah, I. K. (2018): Impacts of Aid for Innovation on Economic Growth in the Sub-Saharan African Countries. Mediterranean Journal of Social Science 9(4): 99-108.

UN. (2015): Transforming Our World: The 2030 Agenda for Sustainable Development. New York: United Nations.

UN. (2017): Resolution Adopted by the General Assembly on 6 July 2017, A/RES/71/313, Work of the Statistical Commission pertaining to the 2030 Agenda for Sustainable Development. New York: United Nations. 
UNCTAD. (2018): World Investment Report 2018. Investment and New Industrial Policies. New York and Geneva: United Nations.

UNCTAD. (2020). UNCTADstat Database. Geneva: United Nations Conference on Trade and Development. https://unctadstat.unctad.org, accessed 11 August 2020.

UNDP. (2019): Human Development Report 2019. Beyond Income, Beyond Averages, Beyond Today: Inequalities in Human Development in the 21st Century. New York: United Nations Development Programme.

Wang, L. - Li, M. - Abbey, C. - Rozelle, S. (2018): Human Capital and the Middle Income Trap: How Many of China's Youth are Going to High School? The Developing Economies 56(2): 82-103.

Woo, W.T. - Lu, M. - Sachs, J. D. - Chen, Z. (2012): A New Economic Growth Engine for China: Escaping the Middle-income Trap by Not Doing More of the Same. Toh Tuk Link, Hackensack, and London: World Scientific Publishing Company and Imperial College Press.

World Bank. (2012): China 2030, Building a Modern, Harmonious, and Creative High-Income Society. Washington DC: World Bank.

World Bank. (2019a): Historical Classifications by Income. http://databank.worldbank.org/data/download/ site-content/OGHIST.xls. accessed 11 August 2020.

World Bank. (2019b): Worldwide Governance Indicators 2019 Update. Washington DC: World Bank.

World Bank. (2020): How the World Bank Classifies Countries. https://datahelpdesk.worldbank.org/ knowledgebase/articles/378834-how-does-the-world-bank-classify-countries. accessed 11 August 2020.

\section{APPENDICES}

Appendix 1. List of the 30 sample countries by income group as of 1990

\begin{tabular}{|l|l|l|}
\hline \multicolumn{2}{|l|}{ Lower-middle-income countries } & Upper-middle-income countries \\
\hline 1. Algeria & 14. Guatemala & 1. Brazil \\
\hline 2. Argentina & 15. Iran & 2. Gabon \\
\hline 3. Belize & 16. Jordan & 3. Mexico \\
\hline 4. Bolivia & 17. Lebanon & 4. South Africa \\
\hline 5. Botswana & 18. Malaysia & \\
\hline 6. Cameroon & 19. Mauritius & \\
\hline 7. Colombia & 20. Morocco & \\
\hline 8. Republic of Congo & 21. Namibia & \\
\hline 9. Costa Rica & 22. Peru & \\
\hline 10. Dominican Republic & 23. Philippines & \\
\hline 11. Ecuador & 24. Senegal & \\
\hline 12. El Salvador & 25. Thailand & \\
\hline 13. Eswanti (Swaziland) & 26. Turkey & \\
\hline
\end{tabular}

Source: authors. 
Appendix 2. Correlation matrix: Governance Indicators and GNI per capita 2003-2017

\begin{tabular}{|c|c|c|c|c|c|c|c|}
\hline & & Corruption & Govt Eff & GNIPC & Atlas & ZODA & ZFDI \\
\hline \multirow[t]{3}{*}{$\begin{array}{l}\text { Control of } \\
\text { Corruption }\end{array}$} & $\begin{array}{l}\text { Pearson } \\
\text { Correlation }\end{array}$ & 1 & $0.610^{* *}$ & $0.277^{* *}$ & $0.299^{* *}$ & 0.002 & 0.049 \\
\hline & $\begin{array}{l}\text { Sig. (2- } \\
\text { tailed) }\end{array}$ & & 0.000 & 0.000 & 0.000 & 0.966 & 0.302 \\
\hline & $\mathrm{N}$ & 450 & 450 & 450 & 450 & 450 & 450 \\
\hline \multirow[t]{3}{*}{$\begin{array}{l}\text { Government } \\
\text { Effectiveness }\end{array}$} & $\begin{array}{l}\text { Pearson } \\
\text { Correlation }\end{array}$ & $0.610^{* *}$ & 1 & $0.463^{* *}$ & $0.474^{* *}$ & 0.062 & $0.210^{* *}$ \\
\hline & $\begin{array}{l}\text { Sig. (2- } \\
\text { tailed) }\end{array}$ & 0.000 & & 0.000 & 0.000 & 0.187 & 0.000 \\
\hline & $\mathrm{N}$ & 450 & 450 & 450 & 450 & 450 & 450 \\
\hline \multirow[t]{3}{*}{ GNIPC } & $\begin{array}{l}\text { Pearson } \\
\text { Correlation }\end{array}$ & $0.277^{* *}$ & $0.463^{* *}$ & 1 & $0.984^{* *}$ & 0.031 & $0.506^{* *}$ \\
\hline & $\begin{array}{l}\text { Sig. (2- } \\
\text { tailed) }\end{array}$ & 0.000 & 0.000 & & 0.000 & 0.514 & 0.000 \\
\hline & $\mathrm{N}$ & 450 & 450 & 450 & 450 & 450 & 450 \\
\hline \multirow[t]{3}{*}{ Atlas } & $\begin{array}{l}\text { Pearson } \\
\text { Correlation }\end{array}$ & $0.299^{* *}$ & $0.474^{* *}$ & $0.984^{* *}$ & 1 & 0.036 & $0.502^{* *}$ \\
\hline & $\begin{array}{l}\text { Sig. (2- } \\
\text { tailed) }\end{array}$ & 0.000 & 0.000 & 0.000 & & 0.441 & 0.000 \\
\hline & $\mathrm{N}$ & 450 & 450 & 450 & 450 & 450 & 450 \\
\hline \multirow[t]{3}{*}{ ZODA } & $\begin{array}{l}\text { Pearson } \\
\text { Correlation }\end{array}$ & 0.002 & 0.062 & 0.031 & 0.036 & 1 & $0.148^{* *}$ \\
\hline & $\begin{array}{l}\text { Sig. (2- } \\
\text { tailed) }\end{array}$ & 0.966 & 0.187 & 0.514 & 0.441 & & 0.002 \\
\hline & $\mathrm{N}$ & 450 & 450 & 450 & 450 & 450 & 450 \\
\hline \multirow[t]{3}{*}{ ZFDI } & $\begin{array}{l}\text { Pearson } \\
\text { Correlation }\end{array}$ & 0.049 & $0.210^{* *}$ & $0.506^{* *}$ & $0.502^{* *}$ & $0.148^{* *}$ & 1 \\
\hline & $\begin{array}{l}\text { Sig. (2- } \\
\text { tailed) }\end{array}$ & 0.302 & 0.000 & 0.000 & 0.000 & 0.002 & \\
\hline & $\mathrm{N}$ & 450 & 450 & 450 & 450 & 450 & 450 \\
\hline
\end{tabular}

**Correlation is significant at the 0.01 level (2-tailed).

Source: authors.

Note: The analysis is for 30 countries over the period 2003-2017. This time period was selected because the annual data series for the World Governance Indicators started in 2003. Corruption refers to perceptions of the 
extent to which public power is exercised for private gain, including both petty and grand forms of corruption, as well as "capture" of the state by elites and private interests (World Bank 2019b). Government effectiveness (Govt Eff) reflects perceptions of the quality of public services, the quality of the civil service, and the degree of its independence from political pressures, the quality of policy formulation and implementation, and the credibility of the government's commitment to such policies (World Bank 2019b).

Open Access. This is an open-access article distributed under the terms of the Creative Commons Attribution 4.0 International License (https://creativecommons.org/licenses/by/4.0), which permits unrestricted use, distribution, and reproduction in any medium, provided the original author and source are credited, a link to the CC License is provided, and changes - if any - are indicated. (SID_1). 